\title{
Programming of adaptive machining for end milling
}

\author{
Y. Petrakov • D. Shuplietsov \\ Igor Sikorsky Kyiv Polytechnic Institute, Kyiv, Ukraine
}

Received: 30 March 2017 / Accepted: 10 April 2017

\begin{abstract}
The problem of performing adaptive machining to program the milling of the detail contours on the CNC machine in case of virtual-location procurement is solved. The correction of the CNC-program by measuring the actual position of the workpiece on the machine table is proposed, and the correction of the control program can be implemented in the result of solving the task of minimax, when looking for such state of its position in space to the maximum allowance on the machined contour was minimal. A mathematical model is developed that unambiguously identifies the position of the workpiece on the machine table according to the measured coordinates of the three points. The developed algorithms automatically search for the correction of the CNC-program for implementing the principle of adaptive machining solution of the problem of minimax. The soft program is created and the method of designing the CNC-program for a virtual basing of the workpiece on the CNC machine is developed. Experimental testing has confirmed efficiency of the developed technique.
\end{abstract}

Keywords: adaptive machining; virtual basing; the task of minimax; contour milling

\section{Introduction}

The traditional technology of machining of details on machine tools is always the first step of the preparation of the draft of the technological bases, which ideally should be the same design. As such bases are used the surface of the detail (workpiece) according to the known rules of combination (unity) databases and the principle of the constancy database [1]. Failure to observe this principle leads to additional errors in the machining process that may necessitate the use of additional operations and increase the complexity of manufacturing. In cases where the combination of design and technological bases is impossible, processing in all operations it is advisable to keep from the same underlying surface. These surfaces are machined to final dimensions and have tighter tolerances between the design provisions and technological base. This position in technology of mechanical engineering has received the name of the principle of unity bases on different operations. Each change of bases causes bias, and when the change is necessary to calculate possible errors [2]. The use of such surfaces in high-quality bases for subsequent operations of technological process of manufacturing the entire detail, presupposes the existence of special devices, providing basing for cylindrical surfaces, flat surfaces, holes for your finger and broken finger, etc.

Currently, modern CNC machines, machining centers allow you to machining the detail completely in one operation or perform all the roughing. This approach is especially important when machining details having functional surfaces of complex 3D shape or differing in large dimensions or both, for example, blades and blades of hydraulic machines, hydraulic turbines, airplane fuselages, etc. [3].
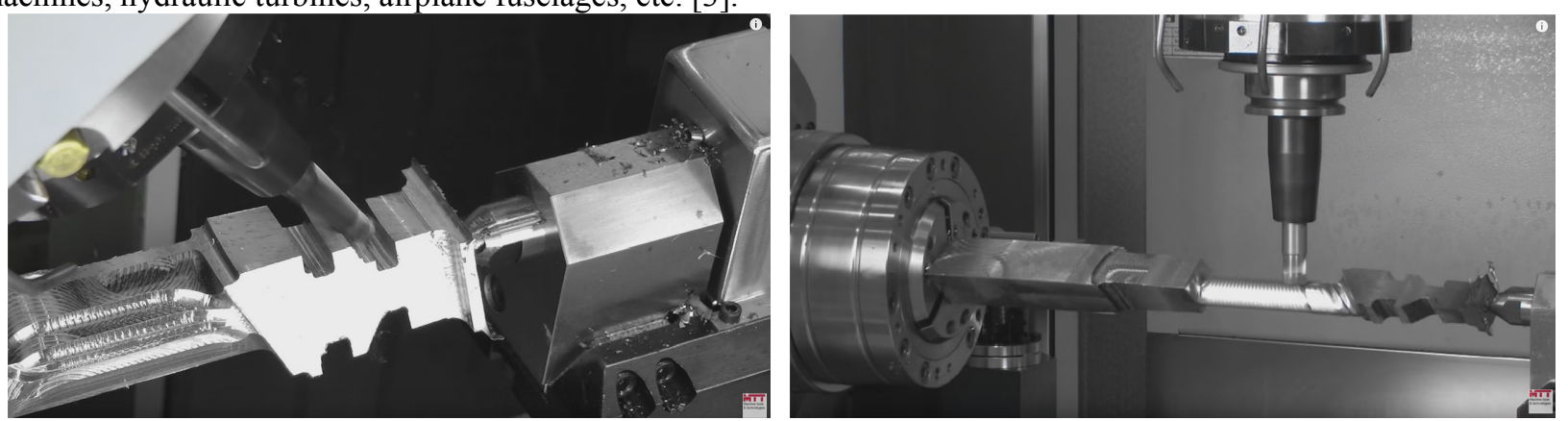

Fig. 1. Turbine blade machining in one operation 
In such cases, a promising technology is the one that allows the billet to be installed on the machine using simple tools such as sticks so that it is possible to process both the surfaces of the design location and the complex $3 \mathrm{D}$ functional surface in one operation. It is important to ensure the optimal location of the part in the body of the workpiece. The task is complicated by the machining of large-sized products, for example, rocket launchers, molds for vehicle dashboards, equipment for vehicle body panels, and the like. For such products, achieving the correct position of the allowance on the machine is the main task that requires long checks and regulation (basing). Often, it is easier to adapt the tool path to a specific process unit, rather than correctly orient the workpiece to ensure the necessary technological allowance [4].

The control program for $\mathrm{CNC}$ machines is usually designed in the CAM-system (Computer Aided Manufacturing) and assumes the availability of mathematical (geometric) models of details and workpieces. In this case, the technologist-programmer chooses the position of the origin of the coordinate system, which must then be combined with the "zeroes" of the machine. However, the developed program can be converted into any other coordinate system, arbitrarily relative to the initial one, without loss of accuracy. Such operations require the determination of the actual position of the workpiece on the machine, which can be performed using the OMV technology (On Machine Verification) offered by Delcam [5]. This direction has received the name of adaptive machining, which is location on the known (PowerINSPECT) technology for measuring the precision of manufacturing detail directly on the machine, but in this case the measurements are not made for verification of the detail, but for linking the coordinate system of the CNC milling machine to the local workpiece coordinate system [6]. It is reported on the application of "virtual basing", when the cost of OMV-measurements before the beginning of milling is much less than in manual basing, and correction of the control program is performed using special algorithms that are not disclosed. It is also not specified whether the developed algorithms provide such a distribution of the allowance for processing, in which the optimization problem presented in [7] for the case of machining large-sized cylindrical parts is solved.

\section{Objective}

Develop an algorithm for optimal distribution of allowance for adaptive machining by end contour milling with the solution of the optimization problem in the virtual basing of the workpiece on a CNC machine and check it in practice.

\section{Statement of the main material}

Mathematical model of control program correction.

The method of virtual basing can be represented on an example of contour machining by milling a detail of an arbitrary shape from a rectangular workpiece. Note that in practice, most of the contour milling operations by the end mill are performed using a rectangular workpiece.

Figure 2 shows the position of the workpiece 1 and detail 2 in the original machine coordinate system when designing the control program in the CAM system. To bind the workpiece according to the traditional technology, it is location in the coordinate system so that a strict orientation is observed with respect to the machine guides using a special device. In this case, the actual position of the workpiece (binding of the control program) is determined by the coordinates of two dimensions: point 3 and point 4 . If the workpiece is installed on the machine without aligning its position and without a special device, it may turn out that its actual position 5 does not ensure milling contour, since the control program corresponds to a position of the detail that extends beyond the workpiece.

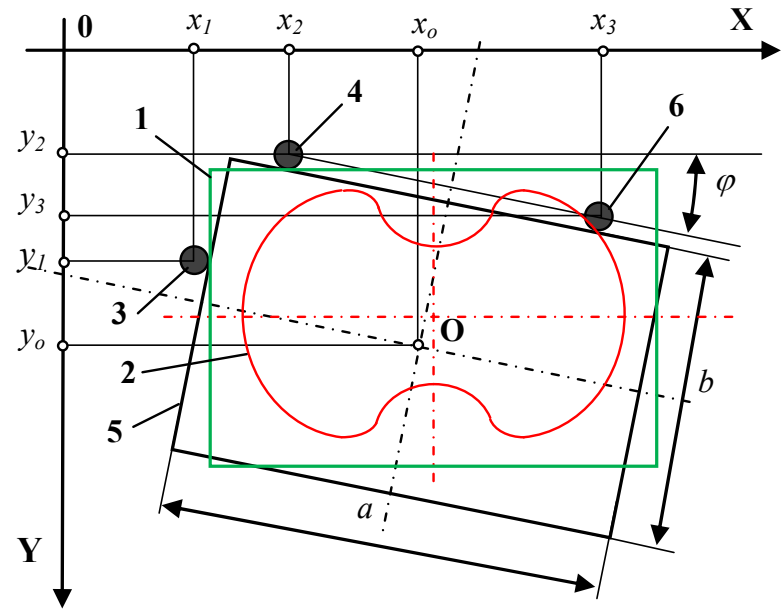

Fig. 2. Calculation scheme for correction of the control program

To determine the actual position of the workpiece, you need another measurement at point 6 . According to the obtained coordinate values to determine the actual rotation angle of the rectangular blank: 


$$
\varphi=\arctan \left(\left(y_{3}-y_{2}\right) /\left(x_{3}-x_{2}\right)\right) .
$$

From geometrical relations of the diagram Fig. 2 it is possible to obtain the equations of the lines that define the location of sides of the rectangle in the coordinate system of the machine. The side AB is described by a line:

$$
y=y_{2}+\left(x-x_{3}\right) \tan \varphi+(b / 2+r) / \cos \varphi,
$$

and the side $D A$ - by the line:

$$
y=y_{1}+\left(x_{1}-x\right) \tan (\pi / 2-\varphi)+(a / 2+r) / \sin \varphi .
$$

Thus, the coordinates of the center, concerning which the control program was designed in the CAM system, occupy a new actual position on the machine:

$$
\left\{\begin{array}{l}
x_{o}=\frac{x_{1} \tan (\pi / 2-\varphi)+(a / 2+r) / \sin \varphi+y_{1}-y_{2}-(b / 2+r) / \cos \varphi+x_{2} \tan \varphi}{\tan \varphi+\tan (\pi / 2-\varphi)} \\
y_{\hat{\imath}}=y_{2}+(b / 2+r) / \cos \varphi-x_{2} \tan \varphi+x_{o} \tan \varphi
\end{array} .\right.
$$

In order to allow machining of the detail contour specified by the program and to fulfill the requirement of preserving the originally designed distribution of the allowance, it is necessary to set the coordinates of the offset of the control program along two coordinate axes and the rotation angle. Thus, the problem is reduced to the solution of the minimax problem: to find such a location of the part (control program) in the workpiece (its actual position), so that the maximum distance between the contour of the part and the workpiece is minimal. In this case, it is necessary to fulfill the following constraint: the entire part is located in the workpiece and does not go anywhere beyond it.

It should be noted here that the mathematical models obtained for calculating the coordinates of the procurement center, with respect to which the control program was designed in the CAM system, are suitable for calculations with a different shape of the blank contour. This property is determined by the fact that the position of any contour on the machine is uniquely determined by the coordinates of its three measured points.

The further solution of the problem in many respects depends on the method of setting the contour of the workpiece and the workpiece. When designing control programs and modeling the machining processes in CAD/CAMsystems, the solid model of the workpiece, the trajectory of the tool and its geometric characteristics are mainly used [7]. The use of solid-state models for the solution of the problem is inappropriate; these models contain a large amount of information not used in this case, which greatly increases the amount of calculations. A new algorithm is proposed, which is location on the framework representation of geometric models, i.e. description of plane geometric contours by two-dimensional arrays of points with a predetermined step. This algorithm has proved itself well in solving not only similar problems, but also for 3D surfaces [8]. It is advisable to search for the optimal position of the detail contour by the Gauss-Seidel method or coordinate descent. In order to implement this method, an algorithm was developed, the enlarged block diagram of which is shown in Fig. 3, a.

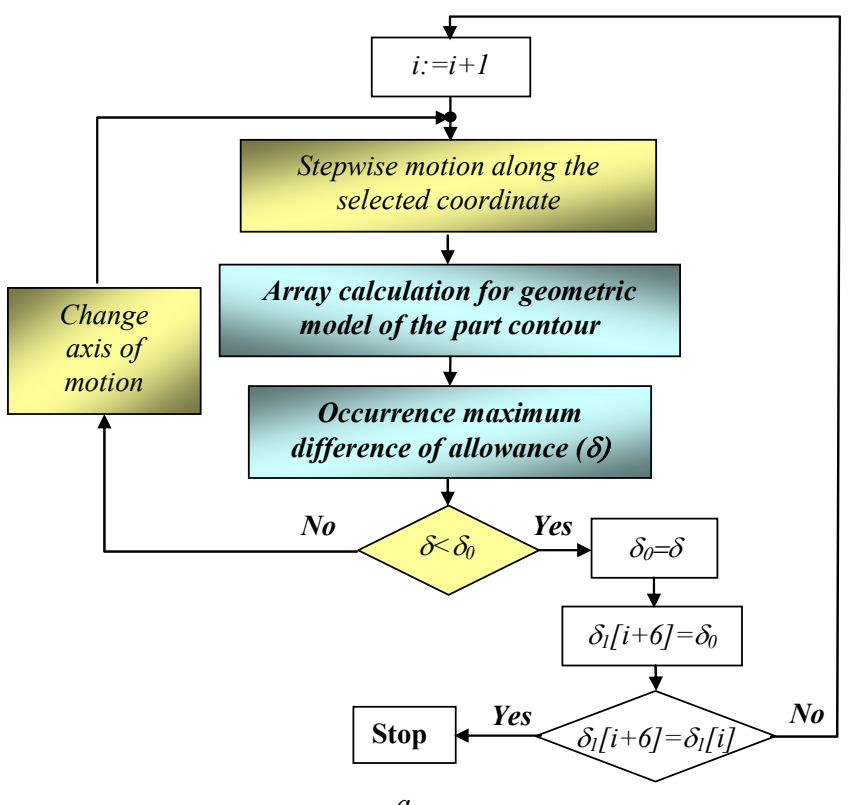

$a$

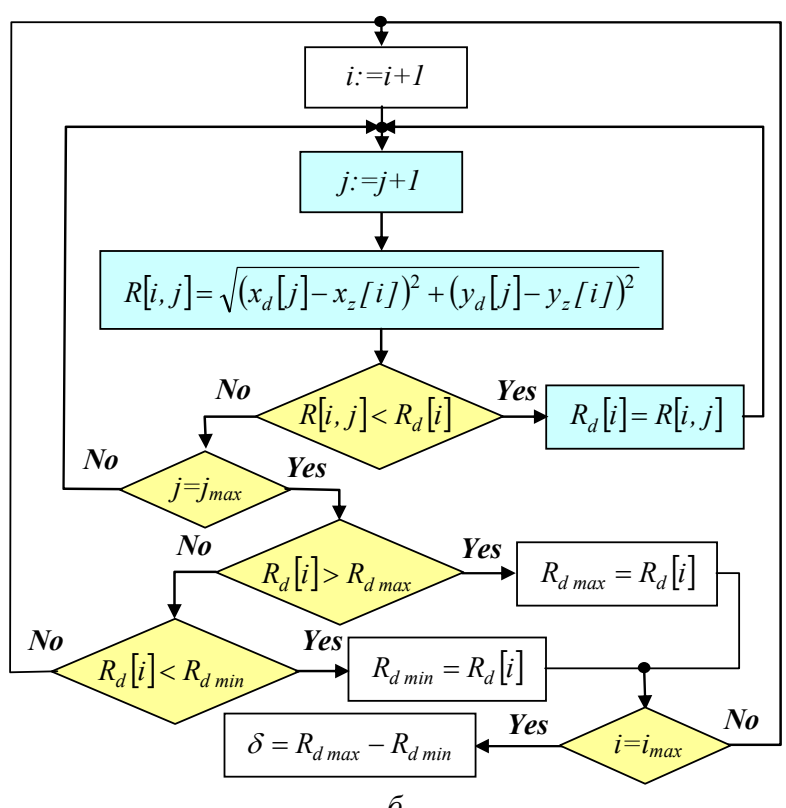

Fig. 3. Control-flow charts:

a - search for the optimal position of the part; $\boldsymbol{\sigma}$-occurrence maximum allowance difference

In the first step $(i=1)$, the initial calculated position of the workpiece is changed by one step along the selected coordinate - either along the X coordinate, or the Y coordinate, or the rotation angle $\varphi$. Then the array of coordinates of 
the points of the geometric model is recalculated in accordance with the new position and the procedure for determining the maximum allowance value, the algorithm of which is presented in Fig. 3, b. The definition is location on calculating the distance from each point of the contour of the part to each point of the contour of the workpiece. The maximum difference calculated in this way is compared with the previously calculated value. Such a process will be repeated until the condition $\delta<\delta_{0}$ is fulfilled, where $\delta_{0}$ is the initially calculated maximum deviation. After this, a step is taken backwards and the algorithm changes the direction of movement: calculations are performed when the position of the workpiece contour is changed from another coordinate and the maximum difference in the allowance is again calculated. Movement in a new direction is also carried out until a similar condition $\delta<\delta_{0}$ is met, when the direction of motion changes. Such cycles are repeated until the condition: $\delta_{1}[i+6]=\delta_{1}[i]$, this means reaching an extreme. Extreme - the minimum of the maximum deviation of the allowance for processing.

The developed algorithms form the mathematical core of the created application program for automatic determination of correction parameters that provide adaptive machining for milling the $2 \mathrm{D}$ contours of details on CNC machines.

\section{Experimentation}

To test the developed method and applied program, experimental studies were carried out on a CNC milling machine MF3 from HAAS (USA). At the same time, the contour of the workpiece was programmed from a rectangular workpiece 1, which was specially installed on the machine table in an arbitrary manner (Fig. 4). Thus, the cases considered in the introduction were simulated, when the orientation of the workpiece in the device is impossible, and its alignment on the machine requires considerable expenditure. The actual position of the workpiece was established from the coordinates of the three measured points with the help of a touch probe 2 from Renishaw.

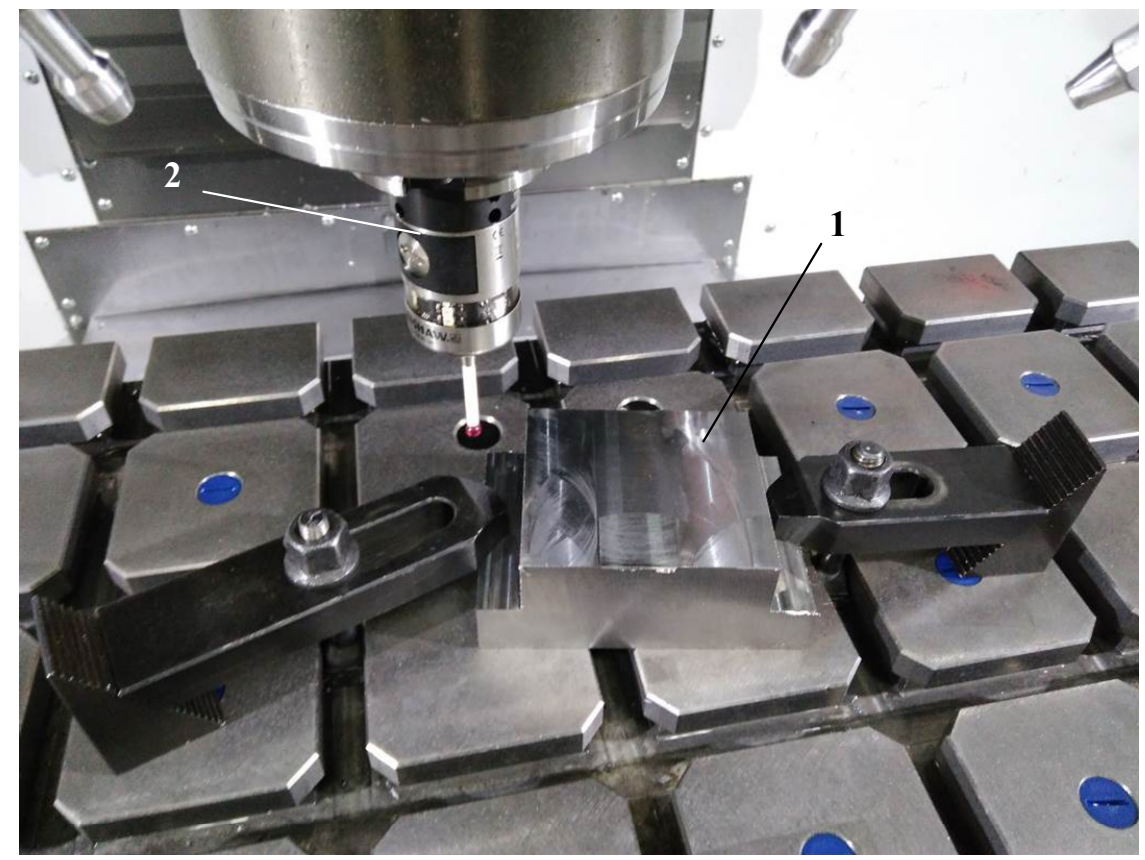

Fig. 4. Measurement of workpiece control points

To create a control program for machining the contour of the workpiece, which is shown in Fig. 2, the CAM system NX 10.0 was used. When preparing a work program in the CAM-system, it is necessary to take into account the position of the working coordinate system (codes G54-G59), since in the future the actions for correction of position and rotation will be performed with respect to this coordinate system. Therefore, the best way to locate the working coordinate system is when its center coincides with the center of mass of the detail.

The search for the correction values of the control program with respect to the actual position of the workpiece was carried out using the developed application program, the interface of which is shown in Fig. 5.

The mathematical core of the program is the dependences (1) - (4) obtained and the algorithms presented in Fig. 3. The contours of the workpiece and the parts formed according to the above rules are loaded in the form of digital models into the program using the appropriate buttons. In the program windows, the measured coordinates of the workpiece location are entered, which are obtained when measuring on the machine. The measurements were performed in manual mode: when setting the $\mathrm{Y}$ coordinate for the reference location and moving to touch the probe of the workpiece surface; When setting the $\mathrm{X}$ coordinates for the guide location and the movement until the probe touches the Y coordinates. After pressing the button "According of measurements", an image of the actual position of the 
workpiece contour 1 appears with the indication of the points 2, 3 and 4 of the basing in the graphics window. The contour 5 of the component is located in the body of the workpiece as originally it was designed in the CAM system.

Obviously, this arrangement of the workpiece does not correspond to the initial setting during the design of the control program, which will cause the tool to overload in some processing areas and may lead to failure. Possible options - a reduction in the initially set cutting depth or redesign in the CAM system unambiguously causes an increase in the processing time of the machine and does not guarantee the fulfillment of adaptive processing requirements.

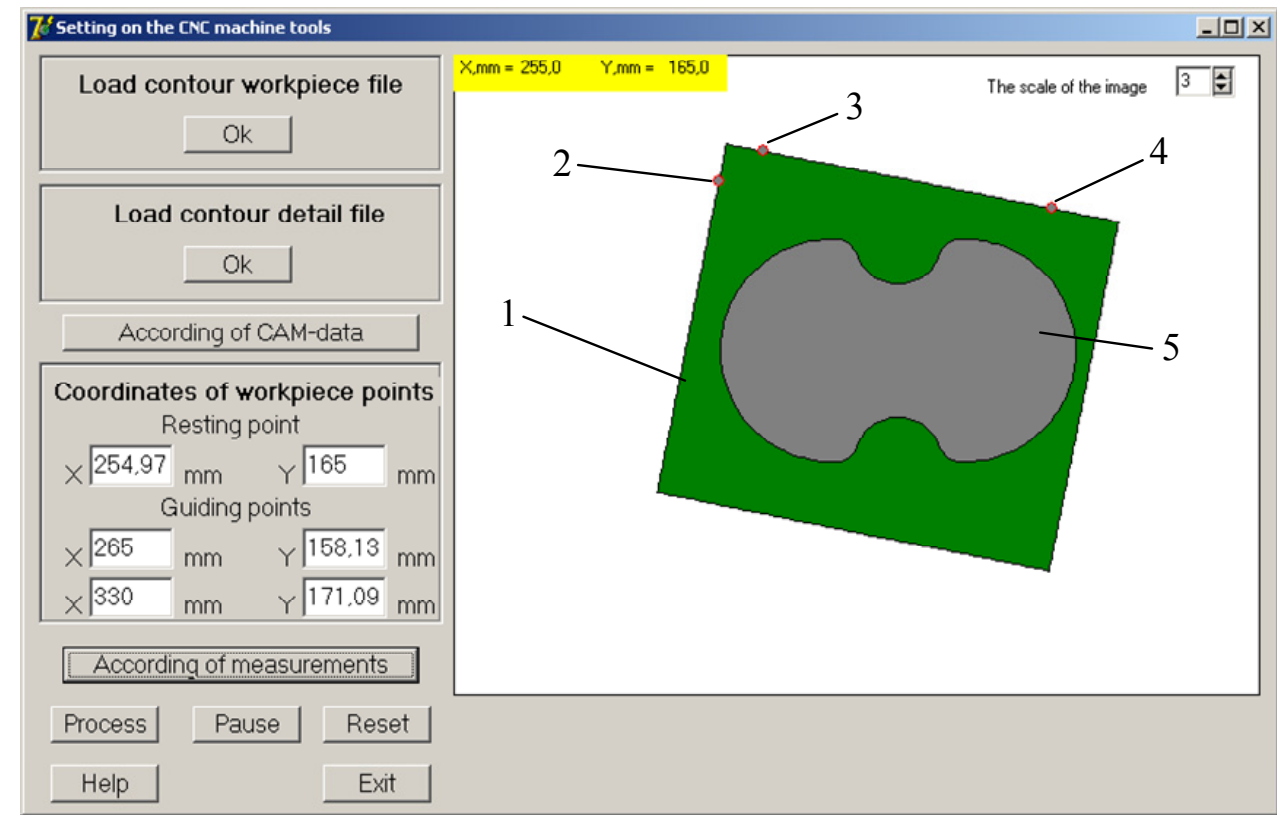

Fig. 5. Program interface of virtual referencing

Pressing the "Process" button automatically searches for the optimal location of the contour of the detail when moving in three coordinates in accordance with the method of searching for the Gauss-Seidel extremum. These operations are provided by algorithms, the block diagrams of which are presented in Fig. 3. In Fig. 6 shows the state of the interface after the end of the search. The search path is shown by the line 1 , which is constructed by the movement of one point of the contour of the detail. As a result, the values of the necessary correction of the control program appear on the interface, which will ensure the implementation of adaptive machining.

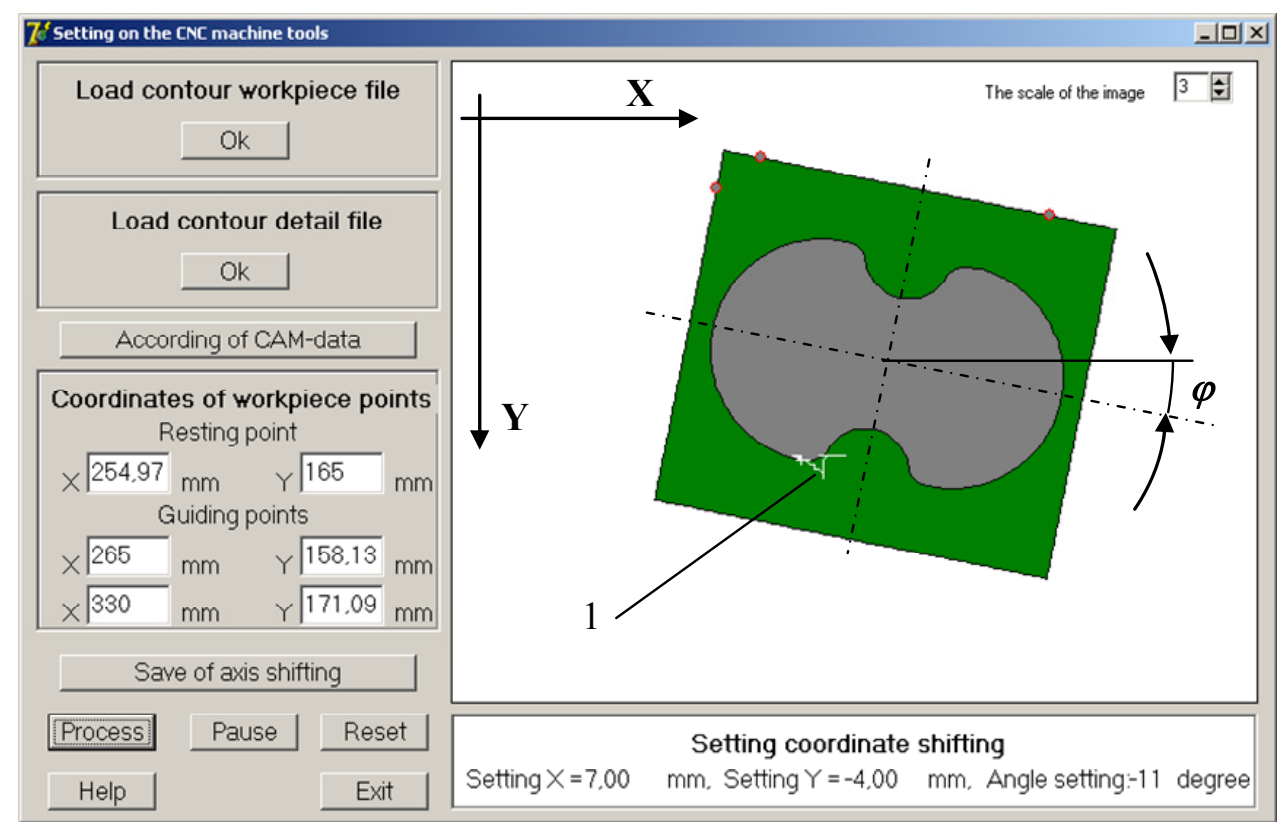

Fig. 6. Program interface in a finish of search 
Location on the results of the application, the control program rotates the processing path using the command line (G68 G17 X0 Y0 R-11.), Where G68 is the rotation function, G17 is the turning plane, X0, Y0 are the coordinates of the rotation center, R-11. - angle of rotation in a clockwise direction in degrees. Correction to the displacement of the working coordinate system along the $\mathrm{X}$ and $\mathrm{Y}$ axes was made directly in its parameters on the $\mathrm{CNC}$ stand of the machine. In Fig. 7 shows the machined part.

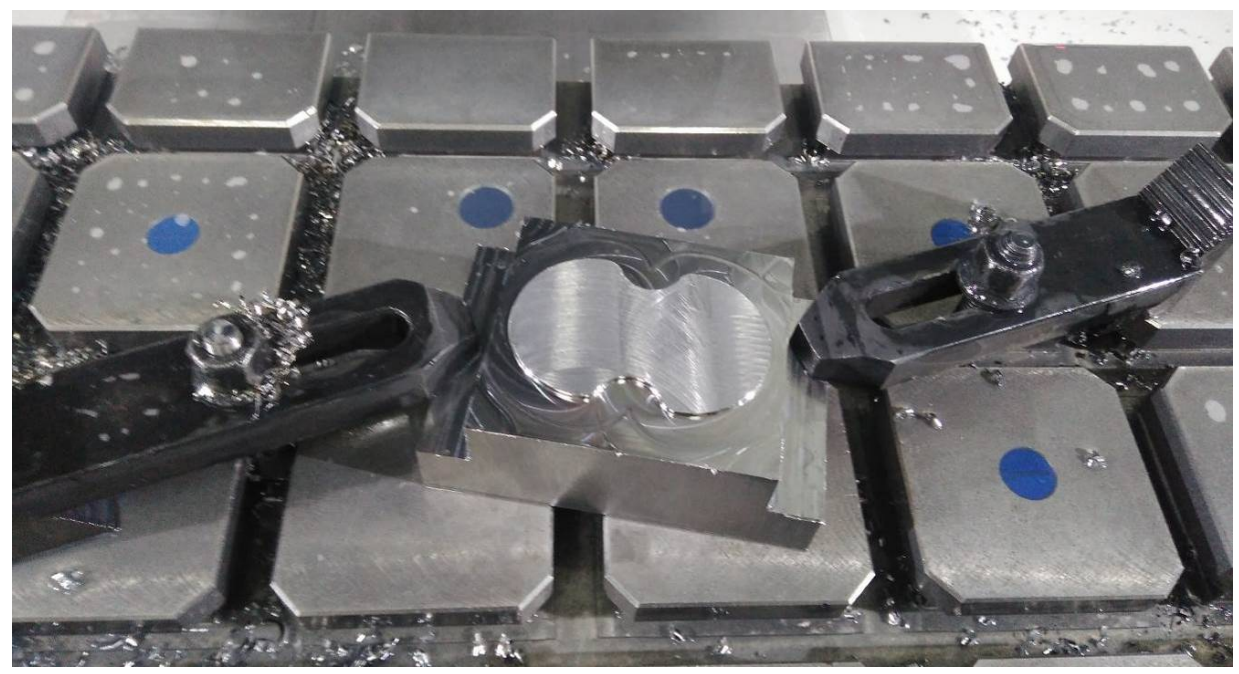

Fig. 7. Machined detail contour

From Fig. 7 that the machined contour of the detail is located in relation to the workpiece as well as in the graphical window of the interface in Fig. 6, which indicates a corrected control program. As a result, the cutting process occurred as it was originally designed in the CAM system.

\title{
Conclusions
}

1. Adaptive machining when programming the milling operations of details contours on a CNC machine in the case of a virtual workpiece basing is performed as a result of minimax task solving, when such position of the control program is searched for the maximum allowable on the machined contour to be minimal.

2. A mathematical model is developed that uniquely determines the position of the workpiece on the machine table from the measured coordinates of its three points. The algorithms for automatic correction of the control program for the implementation of the principle of adaptive processing by solving the minimax task are developed.

3. An application program has been created and a method for designing a control program for the virtual basing of a workpiece on a CNC machine has been developed. The carried out experimental approbation confirmed the effectiveness of the developed technique.

\section{Програмування адаптивної обробки контурного фрезерування}

\section{Ю.В. Петраков, Д.К. Шуплецов}

\begin{abstract}
Анотація. Вирішена задача забезпечення адаптивної обробки при програмуванні операцій фрезерування контурів деталей на верстаті з ЧПК у випадку віртуального базування заготовки. Запропоновано виконувати корекиію управляючої програми за результатами вимірювань фактичного положення заготовки на столі верстату, а корекцію управляючої програми здійснювати за результатами розв'язання задачі мінімаксу, коли шукається таке ї̈ положення в просторі, шзоб максимальний припуск по контуру, щчо обробляється, був мінімальним. Розроблена математична модель, щзо однозначно визначає положення заготовки на столі верстата за виміряними координатами трьох ї точок. Розроблені алгоритми автоматичного пошуку корекції управляючої програми для виконання принципу адаптивної обробки за рахунок вирішення задачі мінімакса. Створена прикладна програма i розроблена методика проектування управляючої програми при віртуальному базуванні заготовки на верстаті з ЧПК. Виконана експериментальна апробація повністю підтвердила ефективність розробленої методики.
\end{abstract}

Ключові слова: адаптивна обробка; віртуальне базування; задача мінимакса; контурне фрезерування 


\section{Программирование адаптивной обработки контурного фрезерования}

\section{Ю.В. Петраков, Д.К. Шуплецов}

Аннотация. Решена задача выполнения адаптивной обработки при программировании операций фрезерования контуров деталей на станке с ЧПУ в случае виртуального базирования заготовки. Предложено выполнять коррекиию управляющей программы по результатам измерения фактического положения заготовки на столе станка, а коррекциию управляющей программы осуществлять в результате решения задачи минимакса, когда ищется такое положение ее положение в пространстве, чтобы максимальный припуск по обрабатывваемому контуру был минимальным. Разработана математическая модель, однозначно определяющая положение заготовки на столе станка по измеренным координатам трех ее точек. Разработаны алгоритмы автоматического поиска коррекции управляющей программы для выполнения приниипа адаптивной обработки решением задачи минимакса. Создана прикладная программа и разработана методика проектирования управляющей программы при виртуальном базировании заготовки на станке с ЧПУ. Проведенная экспериментальная апробация подтвердила эффективность разработанной методики.

Ключевые слова: адаптивная обработка; виртуальное базирование; задача минимакса; контурное фрезерование

\section{References}

1 Kosilova, A.G., Mesheriakova, R.K. and Suslov, A.G. (2001), Spravochnik tehnologa-mashinostroitelia, in Dalskogo A.M. (ed.), Vol 2, no 1, Mashinostroenie, Moscow, Russian.

2 Korchak, S.N., Guzeev, V.I., Butorin, G.I., Viboyshik, V.N., Kulygin, V.L. and Shamarin, V.Y. (2006), Teoreticheskie osnovy bazirovania detaley $i$ rascheta razmerny cepey pri mehanicheskoq obrabotke, Uchebnoe posobie, Komputernaya versia, 2nd edn, in Guzeeva, V.I. (ed.), YUrGU, Cheliabinsk, Russia.

3 Obrabotka lopatki turbiny - YouTube https://www.youtube.com/watch?v=k7JJv8T19io

4 Evchenko, K. (2007), Novie reshenia Delcam dla mehanoobrabotki i dla ludey, SAPR I graphika, no 7, http://www.sapr.ru/article/17844

5 Primenenie tehnologii OMV I adaptivnoy mehanoobrabotki pry proizvodstve izdeliy iz kompozitnih materialov, Umnoe proizvodstvo, vip. 36 ot 12.16 http://www.umpro.ru/index.php?page_id=17\&art_id_1=163\&group_id_4=74

6 Adaptivnaia obrabotka ot kompanii Delcam plc kak integracia mehanoobrabotki $\mathrm{I}$ kontrolia tochnosti izgotovlenia izdeliy, SAPR I graphika, no 1, 2008, pp. 17-20.

7 Sysoev, Y.S. and Tomilin, S.A. (2004), Bazirovanie zagotovok krupnogabagitnih cylindricheskih detaley dla obrabotki rezaniem, Izvestia vuzov, Mashinostroenie, no 1, pp.53-58.

8 Kiselev, I.A. (2012), Geometricheskiy algorytm 3MZBL dla modelirovania processov obrabotki rezaniem. Metodika opisania zagotovki, Vestnik MGTU im. N.E. Baumana. Ser. “Mashinostroenie”, no 6, pp. 158-175.

9 Petrakov, Y.V. and Simuta, R.R. (2014), Modeluvannia procesu zrizuvannia pripusku pid chas konturnogo frezeruvannia, Vestnik Nacionalnogo universitetu "Lvivska polytehnika" Optimizacia vyrobnichih procesiv I tehnichniy control u mashinobuduvanni ta priladobuduvanni, Lviv, pp.142-148.

10 Radu Pavel Adaptive Machining for High Precision Fabrication, http://www.mapyourshow.com/MYS Shared /imts16/handouts/RaduPavelIMTS57.pdf 